\title{
Comparison of Cervicovaginal Cytopathological Samples Collected in Basic Health Units and in Private Clinics in the Midwest of Santa Catarina
}

\section{Comparação de amostras citopatológicas cérvico- vaginais coletadas nas unidades básicas de saúde e em clínicas privadas no meio-oeste de Santa Catarina}

\author{
Bárbara Dallazem ${ }^{1}$ Bibiana Paula Dambrós ${ }^{1}$ Conrado de Oliveira Gamba ${ }^{1}$ Marcelo Perazzoli ${ }^{1}$ \\ Alexandre Kirschnick ${ }^{1}$ \\ 1 Universidade do Oeste de Santa Catarina, Videira, Santa Catarina, Brazil \\ Address for correspondence Bibiana Paula Dambrós, MSc, Universidade \\ do Oeste de Santa Catarina, Rua Paese, 198, 89560-000, Videira, Santa \\ Rev Bras Ginecol Obstet 2018;40:86-91. \\ Catarina, Brazil (e-mail: bibiana.dambros@unoesc.edu.br).
}

\begin{abstract}
Objective To compare the quality of cervicovaginal samples obtained from basic health units (BHUs) of the Unified Health System (SUS) and those obtained from private clinics to screen precursor lesions of cervical cancer.

Methods It was an intervention study whose investigated variables were: adequacy of the samples; presence of epithelia in the samples, and cytopathological results. A total of 940 forms containing the analysis of the biological samples were examined: 470 forms of women attended at BHUs of the SUS and 470 forms of women examined in private clinics in January and February of 2016.

Results All the unsatisfactory samples were collected at BHUs and corresponded to $4 \%$ of the total in this sector $(p<0.0001)$. There was a higher percentage of samples containing only squamous cells in the SUS (43.9\%). There was squamocolumnar junction (SJC) representativeness in $82.1 \%$ of the samples from the private clinics $(p<0.0001)$. Regarding negative results for intraepithelial lesions and/or malignancies, the percentages obtained were $95.9 \%$ and $99.1 \%(p<0.0049)$ in the exams collected in the private system and SUS, respectively. Less serious lesions corresponded

Keywords

- cervix uteri

- biological specimen banks

- neoplasia

- unified health system

- in-service training to $0.89 \%$ of the samples from the SUS and $2.56 \%$ of the tests from the private sector; more serious lesions were not represented in the samples obtained from BHUs, whereas the percentage was $1.49 \%$ in private institutions.

Conclusion Unsatisfactory cervical samples were observed only in exams performed at the SUS. There is a need for guidance and training of professionals who perform this procedure to achieve higher reliability in the results and more safety for women who undergo this preventive test.
\end{abstract}

received

August 11, 2017

accepted

October 27, 2017

published online

December 18, 2017
Copyright $\odot 2018$ by Thieme Revinter

Publicações Ltda, Rio de Janeiro, Brazil
License terms

10.1055/s-0037-1609050. ISSN 0100-7203. c) $(1) \$$ 


\section{Resumo}

Palavras-chave
- colo uterino
- amostras biológicas
- neoplasia
- sistema único de saúde
- capacitação

Objetivo Comparar a qualidade das amostras cérvico-vaginais colhidas no Sistema Único de Saúde (SUS) e nas clínicas privadas para rastrear lesões precursoras de câncer do colo uterino.

Métodos Estudo de intervenção cujas variáveis estudadas foram: adequabilidade da amostra, representação de epitélios na amostra, e resultado do exame citopatológico. Um total de 940 formulários contendo as análises das amostras biológicas foram examinados: 470 formulários de mulheres atendidas nas unidades básicas de saúde do SUS, e 470 formulários de mulheres atendidas em clínicas privadas no período de janeiro a fevereiro de 2016.

Resultados Todas as amostras insatisfatórias foram coletadas nas unidades básicas de saúde do SUS e corresponderam a $4 \%$ do total neste setor $(p<0,0001)$. Observou-se um índice maior de amostras com representatividade somente de células escamosas no SUS (43,9\%). Houve representatividade das células da junção escamo-colunar (JEC) em $82,1 \%$ das amostras colhidas no setor privado $(p<0,0001)$. Em relação aos resultados negativos para lesão intraepitelial e/ou malignidade, os percentuais obtidos foram $95,95 \%$ e $99,1 \%$ ( $p<0,0049)$ para os exames coletados no sistema privado e no SUS, respectivamente. Em relação às lesões menos graves, no SUS obteve-se um resultado de $0,89 \%$ e no sistema privado de $2,56 \%$; as lesões mais graves não foram diagnosticadas no SUS, enquanto que no setor privado representaram $1,49 \%$ dos exames.

Conclusão As amostras cérvico-vaginais insatisfatórias foram observadas somente em exames realizados no SUS; há necessidade de orientação e capacitação dos profissionais que realizam a coleta do exame citopatológico, possibilitando uma maior confiabilidade nos resultados e mais segurança à mulher que se submete a este exame preventivo.

\section{Introduction}

In 1941, the oncotic cervical cytology was developed by George Papanicolaou. It was later renamed the Pap test, and it took shape as a valuable method for the early diagnosis of cervical cancer, because it was accurate, easy to perform and inexpensive. ${ }^{1}$ It proved efficient and has been used to detect precursor lesions of cervical cancer, especially in the early stages, when the treatment presents a high cure rate, which helps to decrease mortality from this disease. ${ }^{2,3}$ According to the Brazilian National Cancer Institute and the international guidelines, the target population for screening of cervical cancer precursor lesions through the cytopathology exam is women from 25 to 64 years old. The test should be performed every 3 years after 2 annual exams with normal results. These screening actions aim to prevent this cancer through early detection and treatment of its precursor lesions. ${ }^{4}$

Cervical neoplasms are the third cause of death among women in Brazil, and overall this type of cancer corresponds to $15 \%$ of tumors in women. ${ }^{5}$ In a study performed in units of the Unified Health System (SUS), it was observed that the pap test presented the highest cost-benefit ratio among all the cervical cancer screening strategies. ${ }^{1}$ Yet, in some regions and countries, doing the exam regularly has not been accompanied by a decrease in mortality because of the existence of false negative results, whose occurrence varies from 6 to $56 \%$. Mistakes in the preanalytical phase, especially those related to the the collection of the material (62\%), stand out among the main causes of these inaccurate outcomes. Consequently, the cytopathology test has been criticized and its validity in the cervical cancer screening programs has been questioned. ${ }^{3,6,7}$

According to Nai et $\mathrm{al}^{8}{ }^{8}$ one of the items advocated by the Bethesda System is the reporting of sample adequacy in medical reports as an important component to guarantee the quality of the sample. Information about the significant presence of the squamocolumnar junction (SCJ) is fundamental to ensure the quality of specimens. According to MacDemay, ${ }^{9}$ the transformation zone, or SCJ, is the region in the cervix where the columnar epithelium was or is being replaced by squamous metaplastic epithelium and is a key place for sample collection. This author also states that the presence of components of the transformation zone is an important measure of proper sampling and that their absence must be considered an indicator of poor sampling. Consequently, it is paramount that samples containing SCJ components are considered suitable for analysis. ${ }^{1}$

Araújo $^{10}$ reports that the main causes of mistakes in the preanalytical phase are associated with the lack of sample adequacy. This means non-representativeness of cells from both mucous membranes- squamous and glandular-that constitute the exocervical region, the endocervical canal and the SCJ, where most cervical carcinomas and precursor 
lesions are located. Hence, it is crucial to understand the SCJ in order to recognize the importance of a well-executed sample collection. ${ }^{11}$

As reported by Manrique et $\mathrm{al}^{12}{ }^{12}$ the quality of the cytopathology exam samples directly influences the efficiency of cervical cancer screening, which justifies the need to monitor specimens, mainly those that result in false negatives. Collection mistakes usually lead to unsatisfactory samples and nonrepresentativeness of epithelia. Amaral et $\mathrm{al}^{13}$ affirmed that cervical cytopathology is considered unsatisfactory when darkening agents, blood, leukocyte infiltrate, thick areas, desiccation, stretching artifacts, cytolysis and contamination hinder the evaluation of over $75 \%$ of epithelial cells, preventing the analysis of the sample and issuing the final result.

In this scenario, healthcare professionals must make sure that they are prepared to perform collection and get the necessary biological material, because guaranteeing sufficient quantities of tissue is fundamental to the success of the process. ${ }^{14}$ The aim of this study was to compare the quality of clinical samples for cytopathology tests gathered by professionals who work in basic health units (BHUs) of the SUS with those from private clinics in order to identify preanalytical mistakes and help develop actions to enable improvements in the adequacy of these samples.

\section{Methods}

It was an epidemiological, quantitative, practical action study, in which retrospective data were collected from the information in cervical cytopathology exam request forms of women assisted in nine SUS BHUs and eight private clinics in Videira, SC; the form had been standardized by the Ministry of Health and was used by the Pathology Institute that performed the exams. The study was approved by the Research Ethics Committee of the institution under the certificate of presentation for ethical appreciation number 59633916.2.0000.5367 and approval report number 1.758.074.

Four hundred and seventy forms containing the analyses of biological samples of women who were assisted in January and February 2016 were gathered from each type of service, totalizing 940 forms. The variables used in these analyses were: adequacy of the samples; presence of epithelia in the samples; and the results of cytopathology exams. Forms indicating that the cervix was not visualized or that the cervix had been surgically removed (total hysterectomy) were excluded from the research.

The variable "presence of epithelia in the samples" was grouped to encompass the representativeness of the SCJ/transformation zone, with at least 10 well-preserved, isolated or grouped, endocervical or metaplastic cells. ${ }^{11}$ The variable "results of exams" was classified into: negative for intraepithelial lesions and/or malignant lesions; less severe lesions (atypical squamous cells of undetermined significance, possibly nonneoplastic [ASC-US]/low-grade squamous intraepithelial lesions [LSIL]), and more severe lesions (atypical squamous cells of undetermined significance, not ruling out high-grade intraepithelial lesions [ASC-H]/atypical glandular cells of undetermined significance $[A G C] /$ high-grade squamous intraepithelial lesions
[HSIL]/ in situ adenocarcinoma [ISA]/invasive adenocarcinoma [IA]), according to the actions advocated by the World Health Organization for the follow-up and treatment of each case. ${ }^{15}$

The records of forms containing acellular or hypocellular material in less than $10 \%$ of the sample, blood, pyocytes, desiccation artifacts, contaminants and significant cell overlay in more than $75 \%$ of the sample were considered unsatisfactory for evaluation of oncotic cervical cytology. ${ }^{13}$ The data were compared using the chi-square test. For the calculation, the expression $\mathrm{X}^{2}=\Sigma[(\mathrm{o}-\mathrm{e}) 2 / \mathrm{e}]$ was used, in which "o" is the frequency observed for each class and "e" is the expected frequency for that class. A significance level of $5 \%$ was adopted, with $p<0.05$ in all analyses. These calculations were ran with the statistics software GraphPad Prism (GraphPad Sofware Inc., La Jolla, CA, USA).

\section{Results}

Unsatisfactory samples were found only in BHUs and corresponded to $4 \%$ (19/470) of the total samples obtained in this sector ( Table 1); $94.7 \%$ of this subgroup (18/19) had desiccation artifacts, and 5.3\% (1/19) contained pyocytes.

Regarding the representative epithelia, the SUS provided samples with a higher percentage of squamous cells only (43.9\%). Squamocolumnar junction cells were observed in $82.1 \%$ of the samples collected in the private institutions (-Table 2). Regarding the cytopathology results, 95.95\% and $99.1 \%$ of the samples provided by private clinics and the SUS,

Table 1 Variations in the adequacy of biological samples collected in basic health units of the Unified Health System and in private clinics

\begin{tabular}{|l|l|l|}
\hline \multirow{2}{*}{ Adequacy } & SUS & Private \\
\cline { 2 - 3 } & $\mathbf{n}(\%)$ & $\mathbf{n}(\%)$ \\
\hline Satisfactory & $451^{\mathrm{b}}(95.95)$ & $470^{\mathrm{a}}(100)$ \\
\hline Unsatisfactory $^{*}$ & $19^{\mathrm{b}}(4)$ & $0^{\mathrm{a}}(0)$ \\
\hline Total & $470(100)$ & $470(100)$ \\
\hline
\end{tabular}

Abbreviations: Private, private clinics; SUS, Unified Health System. *Acellular or hypocellular material in less than $10 \%$ of the smear, blood, pyocytes, desiccation artifacts, contaminants or significant cell overlay in more than $75 \%$ of the smear.

Means followed by different letters in a row, differ in the chi-square test $(p<0.05)$.

Table 2 Presence of epithelia in samples collected in basic health units of the Unified Health System and in private clinics

\begin{tabular}{|l|l|l|}
\hline Presence of epithelia & SUS & Private \\
\cline { 2 - 3 } & $\mathbf{n}(\%)$ & $\mathbf{n}(\%)$ \\
\hline Squamous & $198^{\mathrm{b}}(43.9)$ & $84^{\mathrm{a}}(17.9)$ \\
\hline Squ/Gland/Met & $253^{\mathrm{b}}(56.1)$ & $386^{\mathrm{a}}(82.1)$ \\
\hline Total & $451(100)$ & $470(100)$ \\
\hline
\end{tabular}

Abbreviations: Gland, Glandular; Met, Metaplastic; Private, Private clinics; Squ, Squamous; SUS, Unified Health System.

Means followed by different letters in a row, differ in the chi-square test $(p<0.05)$. 
Table 3 Results of cytopathology analyses of biological samples collected in basic health units of the Unified Health System and in private clinics

\begin{tabular}{|l|l|l|}
\hline Results of the exams & SUS & Private \\
\cline { 2 - 3 } & $\mathbf{n}(\%)$ & $\mathbf{n}(\%)$ \\
\hline $\begin{array}{l}\text { Negative for intraepithelial } \\
\text { and/or malignant lesions }\end{array}$ & $447^{\mathrm{b}}(99.1)$ & $451^{\mathrm{a}}(95.95)$ \\
\hline $\begin{array}{l}\text { Less severe lesions } \\
\text { (ASC-US/LSIL) }\end{array}$ & $4^{\mathrm{b}}(0.89)$ & $12^{\mathrm{a}}(2.56)$ \\
\hline $\begin{array}{l}\text { More severe lesions } \\
\text { (ASC-H/AGC/HSIL/AIS/AI) }\end{array}$ & $0^{\mathrm{b}}(0)$ & $7^{\mathrm{a}}(1.49)$ \\
\hline Total & $451(100)$ & $470(100)$ \\
\hline
\end{tabular}

Abbreviations: AGC, atypical glandular cells of undetermined significance; Al, AIS, Adenocarcinoma in situ; ASC-H, atypical squamous cells of undetermined significance, not ruling out high-grade epithelial lesion; ASC-US, atypical squamous cells of undetermined significance, possibly non-neoplastic; HSIL, high-grade squamous intraepithelial lesion; IA, invasive adenocarcinoma; LSIL, low-grade squamous intraepithelial lesion; SUS, Unified Health System.

Means followed by different letters in a row, differ in the chi-square test $(p<0.05)$.

respectively, did not show intraepithelial and/or malignant lesions.

Less severe lesions (ASC-US/LSIL) were observed in $0.89 \%$ and $2.56 \%$ of the samples from the SUS and private institutions, respectively. More severe lesions (ASC-H/AGC/HSIL/ AIS/IA) were not seen in samples from the SUS, while in specimens collected in private clinics they were found in $1.49 \%$ of the patients (-Table 3 ).

\section{Discussion}

The present study revealed that there was a significant difference regarding the adequacy criteria in cytopathology exams performed in the SUS and those performed in private clinics. Unsatisfactory samples were found in the public service only, most of them exhibiting desiccation artifacts and pyocytes. These results corroborate what was described by Amaral et $a l,{ }^{13}$ who stated that the main problems leading to unsatisfactory cervicovaginal samples were not enough cells in the sample, presence of pyocytes and desiccation. The same issues were observed by Ughini and Calil ${ }^{16}$ in specimens collected in a BHU in Jari, RS; in this case, $4 \%$ of the samples were considered unsatisfactory. Dias et al $^{17}$ also showed that the factors that most hinder the analysis of cytopathology exams are desiccation, blood and insufficient material.

The analysis of samples that present these characteristics requires more time and dedication because a result can be considered only after the confirmation of absence of atypical or dikaryotic cells. In clinical practice, unsatisfactory cervicovaginal samples represent a flaw in the screening of cervical cancer precursor lesions, in addition to causing inconvenience to patients and wasting resources, given that sample adequacy is regarded as the most important component to guarantee the quality of the exam. ${ }^{18,19}$
Sample inadequacy is a technical flaw and subject to preventative measures to avoid or minimize these shortcomings. ${ }^{20}$ Most actions are simple, such as communication between professionals who work in pathology laboratories and those who collect biological material to provide guidance on problems regarding the sample at hand. The shortcoming associated with the presence of pyocytes (5.26\% in the present study) can be corrected with previous cleaning of the cervix, as described by Koss and Gompel. ${ }^{21}$ In cases where the problem is desiccation (94.73\%), guidance on the proper fixation procedure can provide positive results. ${ }^{22}$ However, it must be taken into account that, according to Koss and Gompel, ${ }^{21}$ anatomical and/or physiological factors can lead to longer collection times, causing desiccation, regardless of the skills or knowledge of the professional.

During the research period, it was observed that in the private system, only $17.9 \%$ of the samples did not show SCJ representativeness, while in the SUS that percentage was 43.9\%. Similar results were reported in a study by Ughini and Calil, ${ }^{16}$ who found that the absence of SCJ cells was the most frequent hindering factor in the cytopathology of cervical smears in the samples collected in the BHU of Jari, in Viamão, RS. Amaral et $\mathrm{al}^{13}$ also noticed the absence of SCJ in $40.37 \%$ of the samples in their study, which represented a hindering factor for analysis. Santos et $\mathrm{al}^{23}$ found that in $20.15 \%$ of the analyzed samples, only the squamous epithelium was present, which could expose women to a false negative diagnosis. Collecting gynecologic samples with SCJ representativeness seems to be an easy task, but factors related to patients, such as physical limitations, anatomical characteristics, age, menstrual state, or to professionals, such as experience and training level, can influence the success of the procedure. ${ }^{14}$ An additional problem is that the SUS constantly changes the professionals that carry out the exams, which helps to explain the results of the present study.

There is a consensus among the medical community that SCJ representativeness is an indicator of quality, because this tissue is in the same place where most cervical cancer precursor lesions develop. Professionals have a duty to ensure the presence of this type of material to provide patients with more accurate exams. ${ }^{20}$

Regarding the results of the cytopathological analysis, a significant difference was observed between the negative results for intraepithelial lesions obtained from the SUS (99.1\%) and those obtained from the private system (95.95\%). Mintzer et $\mathrm{al}^{24}$ stated that the representativeness of SCJ cells is related to a higher probability of finding cellular alterations, atypias and lesions because it makes for more effective interpretation. It is possible that the presence of SCJ components may have favored more frequent diagnoses of cellular changes in samples collected in private institutions. This corroborates a study by Amaral et $\mathrm{al}^{13}{ }^{13}$ who found an association between cytopathology results showing alterations and the presence of endocervical cells.

The percentage of samples exhibiting less severe lesions (ASC-US/LSIL) was $0.89 \%$ and $2.56 \%$ for the SUS and the private sector, respectively. More severe lesions (ASC-H/ AGC/HSIL/AIS/IA) were not detected in specimens from the SUS and represented $1.49 \%$ of the samples from private 
clinics. Amaral et al ${ }^{13}$ also reported a 3 -fold to 4 -fold higher frequency of more severe lesions when the samples were suitable for analysis, in comparison with smears presenting hindering factors and absence of endocervical and/or metaplastic cells. A study by Ughini and Calil ${ }^{16}$ revealed no malignancy in $100 \%$ of the samples obtained in BHUs.

According to Tuon et al, ${ }^{25}$ cervical cancer preventive exams present higher variability in the collection process (sensitivity) than in the detection of cellular alterations (specificity). Based on this, it is possible to say that most false negative outcomes result from problems during the collection of the samples. It implies that this stage must be systematized, and the professionals in charge of the sample preparation must be properly trained, taking into account that the exam involves a complex technique, with characteristics that must be observed in order to guarantee the accuracy of the result.

\section{Conclusion}

The present study revealed the presence of unsatisfactory cervical samples in exams performed at the SUS units; this problem was not observed in specimens obtained from private clinics. The inadequacy of the samples from the BHUs is related to low levels of detection of severe lesions. It was also found that the number of SCJ cells in the samples from both services was significantly different. Taking into account that the presence of this tissue in cervical samples is a relevant quality factor, the study points to potential mistakes in the diagnosis of cervical lesions and the need to train professionals who perform the collection of this type of biological material in BHUs. This action would increase the number of adequate samples sent for analysis, which would yield more reliable results and have a significant impact on the screening for cervical cancer.

Conflicts of Interest

There are no conflicts of interest to declare.

\section{Contributors}

Dallazem B., Dambrós B. P., Gamba C. O., Perazzoli M. and Kirschnick A. declared to have contributed with the conception of the study, collection and tabulation, intellectual critical review, drafting of the manuscript and final approval of the version to be published.

\section{Acknowledgments}

This study was partially supported by the Instituto de Patologia (Pathology Institute), located in Videira, SC, Brazil.

\section{References}

1 Caetano R, Vianna CMM, Thuler LCS, Girianelli VR. Custo-efetividade no diagnóstico precoce do câncer de colo uterino no Brasil. Physis 2006;16:99-118. Doi: 10.1590/S0103-73312006000100007

2 Bray F, Loos AH, McCarron P, et al. Trends in cervical squamous cell carcinoma incidence in 13 European countries: changing risk and the effects of screening. Cancer Epidemiol Biomarkers Prev 2005; 14(03):677-686. Doi: 10.1158/1055-9965.EPI-04-0569
3 Tavares SBN, Amaral RG, Manrique EJC, Sousa NLA, Albuquerque ZBP, Zeferino LC. Controle da qualidade em citopatologia cervical: revisão de literatura. Rev Bras Cancerol 2007; 53:355-364

4 Ministério da Saúde. Instituto Nacional de Câncer José Alencar Gomes da Silva. Monitoramento das ações de controle dos cânceres do colo do útero e de mama. Bol Inf Detecção Precoce 2015;6:1-8

5 Martins LFL, Valente JG, Thuler LCS. Factors related to inadequate cervical cancer screening in two Brazilian state capitals. Rev Saude Publica 2009;43(02):318-325. Doi: 10.1590/S0034-89102009000 200013

6 Ázara CZS, Manrique EJC, Alves de Souza NL, Rodrigues AR, Tavares SBN, Amaral RG. External quality control of cervical cytopathology: interlaboratory variability. Acta Cytol 2013;57 (06):585-590. Doi: 10.1159/000353843

7 Tavares SBN, de Souza NL, Manrique EJC, Ázara CZS, da Silveira EA, Amaral RG. Internal quality control for cervical cytopathology: comparison of potential false-negatives detected at rapid prescreening and at 100\% rapid review. Acta Cytol 2014;58(05): 439-445. Doi: 10.1159/000368041

8 Nai GA, Souza KKG, Rodrigues ER, Barbosa RL. [Presence of cells of the cervical transitional zone in cervicovaginal smears in women older than 40 years old]. Rev Bras Ginecol Obstet 2011;33(03): 128-132. Doi: 10.1590/S0100-72032011000300005

9 MacDemay R. The Art and Science of Cytopathology. 2nd ed. Chicago, IL: American Society for Clinical Pathology Press; 2012

10 Araújo SR. Citologia Cervico-Vaginal - Passo a Passo. 2ª ed. Rio de Janeiro, RJ: Di Livros; 2012

11 Amaral AF, Araújo ES, Magalhães JC, Silveira EA, Tavares SB, Amaral RG. [Impact of training about cervical cancer screening on health professionals working in basic health care units] Rev Bras Ginecol Obstet 2014;36(04):182-187. Doi: 10.1590/ S0100-7203201400040004

12 Manrique EJC, Amaral RG, Martins MR, et al. Fatores que comprometem a adequabilidade da amostra citológica cervical. Femina 2009;37:283-287

13 Amaral RG, Manrique EJC, Guimarães JV, et al. [Influence of adequacy of the sample on detection of the precursor lesions of the cervical cancer]. Rev Bras Ginecol Obstet 2008;30(11): 556-560. Doi: 10.1590/S0100-72032008001100005

14 Armstrong N, James V, Dixon-Woods M. The role of primary care professionals in women's experiences of cervical cancer screening: a qualitative study. Fam Pract 2012;29(04):462-466. Doi: 10.1093/fampra/cmr105

15 Ministério da Saúde. Instituto Nacional de Câncer José Alencar Gomes da Silva. Manual de Gestão da Qualidade para Laboratório de Citopatologia. Rio de Janeiro, RJ: INCA; 2012

16 Ughini SFO, Calil LN. Importância da qualidade da coleta do exame preventivo para o diagnóstico das neoplasias glandulares endocervicais e endometriais. Rev Bras Anal Clin 2016;48:41-45

17 Dias MB, Tomazelli JG, Assis M. Rastreamento do câncer de colo do útero no Brasil: análise de dados do Siscolo no período de 2002 a 2006. Epidemiol Serv Saude 2010;19:293-306. Doi: 10.5123/ S1679-49742010000300011

18 Harrison WN, Teale AMJ, Jones SP, Mohammed MA. The impact of the introduction of liquid based cytology on the variation in the proportion of inadequate samples between GP practices. BMC Public Health 2007;7:191. Doi: 10.1186/1471-2458-7-191

19 Damacena AM, Luz LL, Mattos IE. Cervical cancer screening in Teresina, Piauí, Brazil: evaluation study using data of the Cervical Cancer Information System, 2006-2013. Epidemiol Serv Saude 2017;26(01):71-80. Doi: 10.5123/s1679-49742017000100008

20 Ministério da Saúde. Instituto Nacional de Câncer José Alencar Gomes da Silva. Nomenclatura Brasileira para Laudos Citopatológicos Cervicais. $3^{\text {a }}$ ed. Rio de Janeiro, RJ: INCA; 2012

21 Koss LG, Gompel C. Introdução à citologia ginecológica com correlações histológicas e clínicas. In: Koss LG, Gompel C. 
Técnicas de Colheita, de Fixação e de Coloração. São Paulo, SP: Roca; 2006:32-37

22 Secretaria da Saúde. Fundação Oncocentro de São Paulo. Coleta do Papanicolau e Ensino do Auto-Exame da Mama. Manual de Procedimentos Técnicos e Administrativos. $2^{\mathrm{a}}$ ed. São Paulo, SP: FOSP; 2004

23 Santos ML, Moreno MS, Pereira VM. Exame de Papanicolau: qualidade do esfregaço realizado por alunos de enfermagem. Rev Bras Cancerol 2009;55:19-25
24 Mintzer M, Curtis P, Resnick JC, Morrell D. The effect of the quality of Papanicolaou smears on the detection of cytologic abnormalities. Cancer 1999;87(03):113-117. Doi: 10.1002/(SICI)1097-014 2(19990625)87:3<113:AID-CNCR3 > 3.0.CO;2-V

25 Tuon FFB, Bittencourt MS, Panichi MA, Pinto AP. Sensibility and specificity of cytology and colposcopy exams with the histological evaluation of cervical intraepithelial lesions. Rev Assoc Med Bras (1992) 2002;48(02):140-144. Doi: 10.1590/S0104-42302002000 200033 